\title{
MENENTUKAN HARGA KONTRAK BERJANGKA KOMODITAS KEDELAI MENGGUNAKAN MODEL MEAN REVERSION
}

\author{
Wirya Sedana ${ }^{1}$, Komang Dharmawan ${ }^{2 \S}$, Ni Made Asih $^{3}$ \\ ${ }^{1}$ Jurusan Matematika, Fakultas MIPA - Universitas Udayana [Email: wiryasedana12@ gmail.com] \\ ${ }^{2}$ Jurusan Matematika, Fakultas MIPA - Universitas Udayana [Email: k.dharmawan@ gmail.com] \\ ${ }^{3}$ Jurusan Matematika, Fakultas MIPA - Universitas Udayana [Email: asihmath77@gmail.com] \\ ${ }^{\S}$ Corresponding Author
}

\begin{abstract}
It has been discussed in many literatures that commodity prices tend to follow mean reversion model. This means that when there is a jump price in certain time, the price will revert to the mean price in the future. In this research, the method to determine the existence of mean-reversion of soybean price dynamics is discussed. Then, the future contract of soybeans is calculated using mean-reversion simulation and the spot-future parity theorem. Both methods are applied to the closing price of soybeans for the period of 19 September 2011 to 28 April 2016. The results show that the future contract price calculated by Model Mean-Reversion simulation under estimate the future contract price determined by the spot-future parity theorem.
\end{abstract}

Keywords: Derivative securities, futures contract, soybeans commodity, Model Mean Reversion, Spot-futures parity theorem.

\section{PENDAHULUAN}

Sekuritas derivatif adalah suatu sekuritas yang sebagian nilainya dipengaruhi oleh sekuritas lain. Pasar keuangan derivatif dikelompokkan berdasarkan sifat dari aktiva yang dijadikan sebagai induknya, seperti saham, obligasi, komoditas, dan berbagai macam indeks. Pasar keuangan derivatif juga dapat dikelompokkan berdasarkan kontraknya antara lain future contracts, forward contracts, option contracts, swap contracts dan kombinasi dari beberapa kontrak sekaligus (Siahaan, 2008). Semua instrumen derivatif adalah kontrak antara dua pihak pembeli dan penjual yang di dalam kontraknya berbagai hal telah disepakati bersama pada saat ditetapkan, tetapi realisasinya atau pelaksanaan hal tersebut adalah nanti pada kurun waktu tertentu di masa yang akan datang. Komoditas adalah sesuatu benda nyata yang relatif mudah diperdagangkan, dapat diserahkan secara fisik, dapat disimpan untuk suatu jangka waktu tertentu dan dapat dipertukarkan dengan produk lainnya dengan jenis yang sama, yang biasanya dapat dibeli atau dijual oleh investor melalui bursa berjangka (Tandelilin, 2011). Secara lebih umum, komoditas adalah suatu produk yang diperdagangkan, termasuk valuta asing, instrumen keuangan dan indeks (Hull, 2002). Komoditas dari sektor pertanian dan sektor industri merupakan hal yang penting bagi perekonomian Indonesia. Di Indonesia, sektor industri berkaitan erat dengan sektor pertanian terutama industri yang menggunakan bahan baku dari hasil pertanian. Masalah sering timbul ketika bahan baku komoditas yang diperlukan untuk sektor industri tidak terpenuhi dengan baik. Hal ini disebabkan oleh kebutuhan bahan baku industri yang tinggi dan tidak diimbangi dengan produksi dari sektor pertanian. Dengan demikian untuk memenuhi kebutuhan bahan baku komoditas tersebut, pemerintah harus mengimpor hasil pertanian. Ketergantungan akan bahan baku impor menyebabkan harga komoditas lokal akan dipengaruhi oleh harga 
komoditas dunia. Harga komoditas dalam negeri menjadi tidak stabil dan cenderung mengalami perubahan dari tahun ke tahun. Dalam jangka pendek dapat dikatakan bahwa perubahan harga komoditas cenderung fluktuatif (Bappenas, 2015). Salah satu alternatif penyelesaian masalah ini adalah melakukan perdagangan dengan kontrak berjangka (futures contract). Kontrak berjangka akan membantu harga komoditas yang ada di pasaran menjadi lebih stabil dan mengurangi harga dapat melonjak tinggi. Dalam hal ini terdapat metode yang bisa digunakan untuk menentukan harga kontrak berjangka, yaitu Markov Chain Monte Carlo (Rubinstein \& Kroese, 2008), Spot-Future Parity Theorem, dan salah satunya adalah Model Mean Reversion (Brigo, et al, 2009). Metode ini menyatakan bahwa harga akan cenderung kembali ke tingkat nilai rata-rata. Kalau harga naik atau menurun, yang artinya menjauh dari nilai rata-rata, maka pada saatnya nanti, harga akan berbalik arah, kembali ke tingkat harga rata-rata (Dharmawan, 2016).

\section{METODE PENELITIAN}

Penelitian yang dilakukan adalah studi kasus terhadap harga kontrak berjangka komoditas kedelai. Peneliti menentukan harga kontrak berjangka dari komoditas kedelai melalui perhitungan data historis harga komoditas kedelai. Perhitungan meliputi pengestimasian nilai parameter, yang kemudian dilakukan simulasi harga komoditas pada waktu $T$ menggunakan vasicek, dan penentuan harga kontrak berjangka komoditas kedelai.Langkahlangkah untuk menentukan harga kontrak berjangka dari suatu nilai tukar, yaitu: (1) Mengumpulkan data historis harga komoditas yang akan digunakan; (2) Menghitung tingkat pengembalian (return) dari harga penutupan (close) komoditas kedelai; (3) Menghitung nilai masukan deskriptif statistik rata-rata data (mean), ragam data (variance), sebaran data (standar deviation), kepencongan data (skewness), dan kurtosis dari data return komoditas kedelai; (4) Mengestimasi nilai parameter yaitu $\left(S_{t+1}-S_{t}\right) / S_{t} \quad$ sebagai variable respon, dan $S_{t}$ sebagai variabel bebas menggunakan metode Regresi; (5) Setelah diperoleh hasil berupa $\hat{\lambda}, \hat{\mu}, \hat{\sigma}$ pada langkah 4 ., kemudian di lakukan simulasi dengan menggunakan Vasicek model; (6) Kemudian dari langkah ke 5 akan di peroleh output berupa harga komoditas $\left(S_{t}\right)$. Selanjutnya akan ditentukan harga kontrak berjangka komoditas $\left(F_{t}\right)$; (7) Setelah harga kontrak ditentukan dengan Model Mean Reversion kemudian akan ditentukan harga kontrak berjangka komoditas kedelai menggunakan metode Spot-Future Parity Theorem; (8) Langkah terakhir adalah membandingkan komoditas kedelai dengan menggunakan Model Mean Reversion dan SpotFuture Parity Theorem, kemudian dilihat hasil yang diperoleh, untuk kemudian dibandingkan nilai terbesar dan terkecil dari nilai harga kontrak tersebut;

\section{HASIL DAN PEMBAHASAN}

\section{Pengolahan Data}

Dalam penelitian nilai kontrak berjangka komoditas kedelai (Teucrium Soybean ETF (SOYB)) dihitung menggunakan simulasi Mean Reversion Aritmatik (MRA) dan Mean Reversion Geometrik (MRG) (Smith, 2010).

\section{Harga Penutupan Harian (close price)}

Harga penutupan harian dari komoditas kedelai (Teucrium Soybean ETF (SOYB)) yang dicatat pada periode 19 September 2011 sampai dengan 28 April 2016 disajikan dalam bentuk grafik pada Gambar 1.

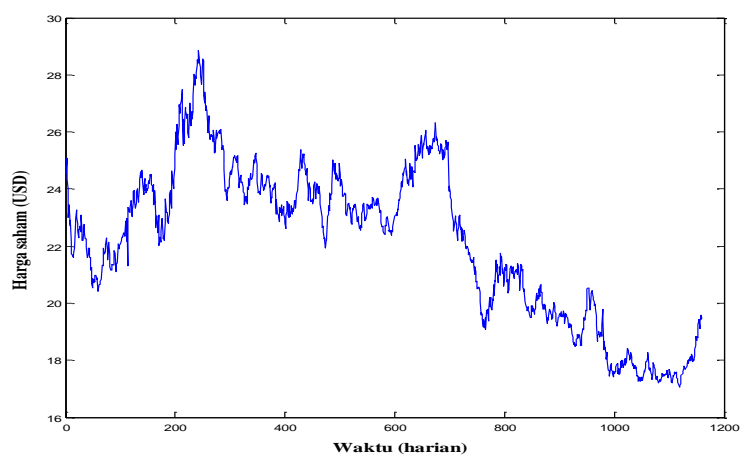

Gambar1. Plot Harga Penutupan (close) komoditas kedelai periode 19 September 2011 sampai dengan 28 April 2016. 
Berdasarkan grafik pada Gambar 1 dapat diamati kenaikan harga pada periode September 2011-April 2016 menuju ke harga rata-rata.

\section{Menentukan Nilai Return Komoditas Kedelai}

Menentukan nilai $r_{t}$ (Return saham pada waktu $t$ ) dengan persamaan berikut:

$$
r_{t}=\ln \left(\frac{S_{t+1}}{S_{t}}\right)
$$

maka didapat hasil tingkat pengembalian seperti tersaji pada Gambar 2.

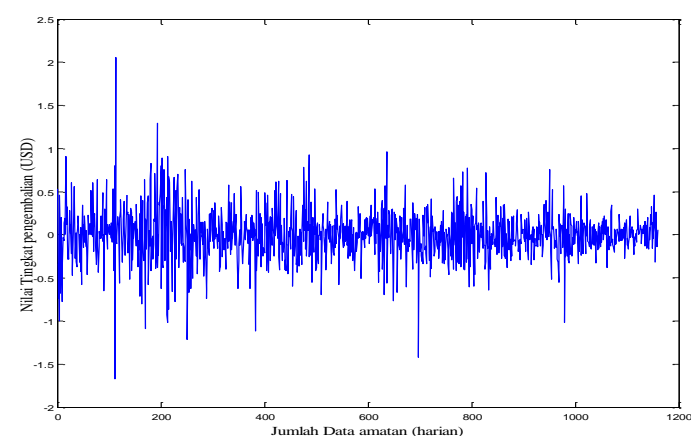

Gambar 2. Plot Return komoditas kedelai pada periode 19 September 2011-28 April 2016

\section{Parameter-Parameter dalam Penentuan Harga Kontrak Berjangka}

Parameter yang digunakan untuk menentukan harga kontrak berjangka meliputi $S_{0}$ ( harga saham awal), $T$ (waktu jatuh tempo kontrak), $t$ (waktu), $r$ (suku bunga bebas resiko yang dikeluarkan oleh pihak yang berwenang di tempat melakukan transaksi kontrak berjangka), $\quad \mu$ (mean), $\quad \sigma$ (variance), dan $\lambda$ (kecepatan kembali ke rata-rata). Nilai dari $S_{0}$ dapat di lihat pada data historis penutupan harga komoditas (Teucrium Soybean ETF (SOYB), 2011-2015) terbaru yaitu pada tanggal 28 April 2016 sebesar 19,5. Sedangkan waktu untuk jatuh tempo kontrak berjangka ditentukan selama tiga bulan, dengan suku bunga bebas resiko sebesar $r=7,5 \%$ yang mengacu ke Bank Indonesia.

\section{Penentuan Nilai Mean, Varians, Skewnes, Kurtosis}

Nilai masukan deskriptif yang akan dicari dalam proses ini, didapat dengan memanfaatkan data historis harga penutupan komoditas kedelai periode 19 September 2011 sampai dengan 28 April 2016. Langkah pertama yang akan dilakukan adalah menghitung nilai Mean, kemudian variance, Standar Deviation, Skewness, dan Kurtosis dari harga penutupan komoditas kedelai dengan bantuan perintah program Matlab 2013, sehingga didapat hasil pada Tabel 1 .

Tabel 1. Nilai Masukan Deskriptif data historis harga penutupan komoditas kedelai

\begin{tabular}{|c|c|}
\hline Mean & -0.0001987 \\
\hline Variance & 0.00016715 \\
\hline Standar Deviation & 0.0129 \\
\hline Skewness & 0.0812 \\
\hline Kurtosis & 7.2938 \\
\hline
\end{tabular}

Dari Tabel 1 terlihat bahwa data komoditas kedelai memiliki bentuk yang tidak simetris. Hal ini ditunjukkan dengan adanya kemencengan data kearah kanan, dan data juga menunjukkan adanya ekor gemuk (fat tail). Hal ini dapat dilihat dari nilai kurtosis yang cukup besar yaitu 7.2938, dimana nilai normalnya adalah 3. Ekor gemuk ini disebabkan oleh adanya banyak data ekstrim atau banyaknya lompatan-lompatan pada data.

\section{Estimasi Parameter dengan MRA dan MRG}

Untuk mensimulasikan proses mean Reversion, perlu dilakukan estimasi parameter $\lambda, \mu$ dan $\sigma$. Dalam penaksiran ini diasumsikan bahwa parameter tersebut tetap konstan selama periode waktu estimasi. Maka langkah-langkah yang akan dilakukan untuk mengestimasi parameter adalah sebagai berikut :

1. Hitung perubahan harga komoditas $\left(S_{t+1}-S_{t}\right)$ untuk setiap periode $t$ dimana $t=0,1, \cdots T-$.

2. Melakukan regresi linier dengan $\left(S_{t+1}-\right.$ $S_{t}$ ) sebagai variabel respon dan $S_{t}$ sebagai variabel bebas. Dalam Excel, klik Data tab, klik Analisis Data, pilih regresi dari alat analisis. Dengan MATLAB's Statistik Toolbox, menggunakan regress $(\mathrm{Y}, \mathrm{X})$ function.

3. Selain menggunakan sekater plot seperti langkah 2 , dapat juga dilihat nilai dari $p$ - 
value. Dari output regresi, terlihat bahwa $p$ value berkisar antara 5\%-7\%.

4. Nilai $\hat{\lambda}$, yaitu parameter yang menyatakan kecepatan kembali ke rataan, diestimasi dari negatif dari koefisien variabel $X$, dalam hal in $\hat{\lambda}=0.0059$

5. Estimasi nilai rataan jangka panjang didapat dari hasil bagi intercept dengan variabel $X$. Dalam hal ini $\hat{\mu}=0.13419 /(-0.0059)=$ $-22,7440$.

6. Volatilitas dari proses mean-reversion diestimasi dari standar error regresi, yaitu $\hat{\sigma}=0.2949$

\section{Simulasi Harga Kontrak dengan MRA dan MRG}

Simulasi Mean Reversion Aritmatik dan Mean Reversion Geometrik akan mengikutsertakan pembangkitan bilangan acak. Algoritma ini memerlukan pengulangan (repetisi) dan perhitungan yang amat kompleks, sehingga umumnya dilakukan dengan menggunakan komputer. Simulasi ini diproses melalui banyak iterasi dengan variabel acak yang berbeda dan untuk memperkirakan nilai komoditas kedelai yang akan datang dengan merata- ratakan kemungkinan yang terjadi. Dimana dilakukan beberapa simulasi kemudian harga komoditas yang akan dapat diperoleh dengan merata-ratakan simulasi yang terjadi. Simulasi dilakukan dengan memasukkan nilainilai dari parameter yang telah di peroleh dari estimasi parameter-parameter awal yaitu $\hat{\mu}(-22,7440), \hat{\lambda}(0.0059)$, dan $\hat{\sigma}(0.2949)$ ke dalam perintah pada program Matlab. Simulasi dijalankan dengan menggunakan harga awal sebesar 24,55 dan dalam jangka waktu kontrak selama 3 bulan atau 66 hari, karena dalam seminggu bursa berjangka libur pada hari sabtu dan minggu. Agar pengamatan lebih mudah dilakukan, maka simulasi yang akan ditampilkan hanya sebatas 10 kali simulasi, yang disajikan dalam bentuk grafik pada Gambar 3 dan Gambar 4. Tetapi pada penelitian ini hasil yang dipergunakan adalah hasil dari simulasi yang dijalankan sebanyak 100.000 simulasi.
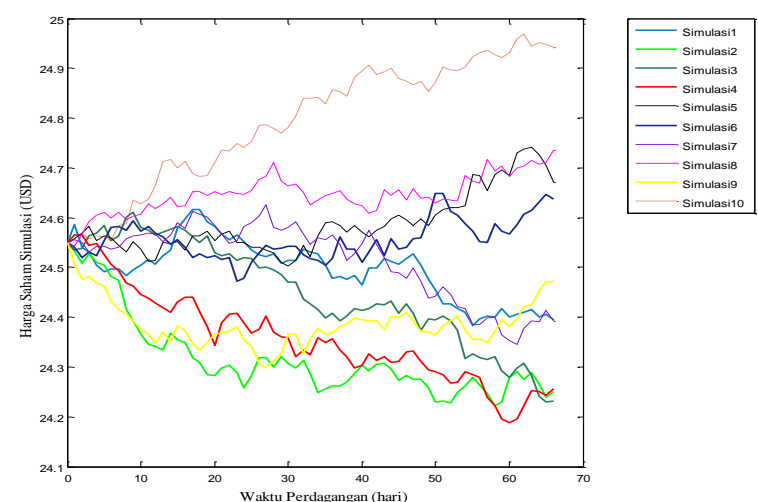

Gambar 3. Plot Simulasi Harga $\left(S_{t}\right)$ sebanyak 10 kali simulasi selama 3 bulan dengan MRA

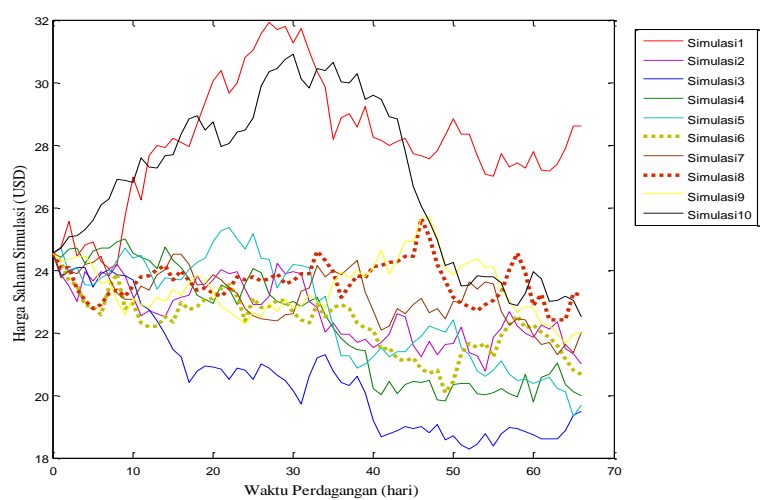

Gambar 4. Plot Simulasi $\left(S_{t}\right)$ sebanyak 10 kali simulasi selama 3 bulan dengan MRG

\section{Penentuan Harga Kontrak Berjangka Komoditas Kedelai dengan menggunakan Model Mean Reversion}

Penentuan harga kontrak berjangka komoditas kedelai pada penelitian ini akan dicari dengan menggunakan 2 metode yaitu Model Mean Reversion (Gillespie, 1996) dan Spot-future Parity theorem (Ermogenous, 2005) yang kemudian akan dibandingkan nilai terbesar dan terkecil dari kedua harga kontrak tersebut.

a) Penentuan Kontrak Berjangka Komoditas Kedelai Menggunakan MRA dan MRG

Nilai kontrak berjangka komoditas emas $\left(F_{t}\right) \quad$ dicari menggunakan harga komoditas kedelai $\left(S_{t}\right)$ yang telah didapatkan melalui simulasi Mean Reversion Vasicek Model pada 
Gambar 3, dan Gambar 4. Nilai ( $S_{t}$ ) rata-rata yang didapat dimasukkan pada persamaan (2.1) dengan nilai $\left(e^{-r(T-t)}\right)$ sebesar 0.981425 dan suku bunga bebas resiko sebesar 7,5\% yang dikeluarkan oleh bank Indonesia, sehinggga akan didapat 4 harga pada Tabel 2. Rata-rata dari seluruh nilai merupakann harga akhir kontrak yang dicari.

Pada Tabel 2 akan diperlihatkan untuk harga kontrak berjangka yang dilakukan dengan jumlah simulasi yang lebih banyak dan masing-masing dari waktu simulasi tersebut dijalankan pada program Matlab dan harga kontrak yang akan digunakan dalam penelitian ini adalah harga kontrak dengan simulasi sebanyak 100.000 simulasi, karena semakin banyak simulasi yang akan dilakukan maka nilai yang di dapat akan semakin konvergen ke harga aslinya.

Tabel 2. Harga kontrak Berjangka menggunakan simulasi MRA dan MRG

\begin{tabular}{|c|c|c|c|c|c|}
\hline \multirow{2}{*}{ Jumlah Simulasi } & \multirow{2}{*}{ Waktu } & \multicolumn{2}{|c|}{$S_{t}$} & \multicolumn{2}{c|}{$F_{t}$} \\
\cline { 3 - 6 } & & MRA & MRG & MRA & MRG \\
\hline 100 & $0.172 \mathrm{~s}$ & 24.5501 & 24.4325 & 24.09407 & 23.97866 \\
\hline 1000 & $4.861 \mathrm{~s}$ & 24.4246 & 24.7473 & 23.97091 & 24.28761 \\
\hline 10000 & $24.358 \mathrm{~s}$ & 24.4666 & 23.8436 & 24.01213 & 23.4007 \\
\hline 100000 & $419.738 \mathrm{~s}$ & 24.5560 & 24.6031 & 24.09986 & 24.14609 \\
\hline
\end{tabular}

b) Penentuan Kontrak Berjangka Komoditas Kedelai menggunakan Spot-future Parity Theorem.

Penentuan harga kontrak berjangka komoditas kedelai menggunakan Spot-future parity theorem, hanya melibatkan parameterparameter seperti harga awal komoditas, tingkat suku bunga bebas resiko, biaya penyimpanan gudang dan waktu. Sehingga dalam perhitungannya dapat dihitung menggunakan persamaan (2.19). Dari data historis komoditas kedelai pada lampiran I, telah diketahui nilainilai masukan yang akan dipakai dalam penentuan kontrak berjangka emas seperti harga awal $\left(S_{t}\right)$ yang merupakan harga terakhir dari data sebelum kontrak tersebut dibuat, $(r)$ yang merupakan suku bunga bebas resiko sebesar 7,5\% yang dikeluarkan oleh bank Indonesia, (c) merupakan nilai biaya penyimpanan gudang yang sedah diasumsikan nol, dan $(t)$ yang merupakan waktu berlangsungnya kontrak selama 3 bulan atau 0,25 tahun.
Tabel 3. Nilai Masukan Untuk Menentukan Kontrak menggunakan Spot-future Parity Theorem

\begin{tabular}{|c|c|}
\hline Variabel & Nilai \\
\hline$S_{t}$ & 24,55 \\
\hline$r$ & $7,5 \%(0.075)$ \\
\hline$c$ & 0 \\
\hline$t$ & 0,25 \\
\hline
\end{tabular}

Perhitungan nilai kontrak berjangka komoditas kedelai menggunakan Spot-future Parity Theorem.

$$
\begin{gathered}
F_{t}=S_{t}(1+r+c)^{-t} \\
F_{t}=24,55(1+0,075+0)^{-0,25} \\
F_{t}=24,55(0,982082) \\
F_{t}=24,11012
\end{gathered}
$$

Dengan menggunakan Spot-future Parity Theorem maka hasil kontrak berjangka komoditas kedelai yang didapat adalah sebesar 24,11012 USD.

\section{KESIMPULAN}

Hasil simulasi Mean Reversion Vasicek Model memberikan harga kontrak berjangka sebesar 24,09986 USD sedangkan spot-future parity theorem memberikan harga kontrak berjangka sebesar 24,11012 USD. Berdasarkan kedua hasil tersebut dapat disimpulkan bahwa harga kontrak berjangka yang didapat dengan 
menggunakan simulasi Mean Reversion Vasicek Model memeberikan harga yang lebih kecil (murah) dibandingkan spot-future parity theorem, ini dilihat dari parameter-parameter yang dilibatkan dalam penentuan harga kontrak berjangka yang dihasilkan.

Dalam penentuan harga kontrak berjangka menggunakan metode simulasi Mean Reversion Vasicek parameter-parameter yang dilibatkan lebih banyak seperti: sigma, mu, skewness, lamda, dan kurtosis. Sedangkan pada spotfuture parity theorem, dalam menentukan harga kontrak berjangka parameter-parameter tersebut tidak dilibatkan atau diabaikan.

\section{DAFTAR PUSTAKA}

Bappenas. (2015).

http://www.bappenas.go.id/files/3713/9346/

9271/RPJMN_Bidang_Pangan_dan_Pertan ian_2015-2019.pdf. Retrieved Februari 6, 2015, from www.bappenas.go.id.

Brigo D., Dalessandro A., Neugebauer M., Triki F. (2009). A Stochastic Processes Toolkit for Risk Management. Journal of Risk Management in Financial Institutions, 3, London: Departmen of Mathematics , Imperial Colege.
Dharmawan, K. (2016). Pricing European Options on Agriculture Commodity Prices Using Mean-Reversion Model with Jump Diffusion. The International Conference on Applied Statistics Prociding, Bandung, September 27-28, 2016

Ermogenous, A. B. (2005). Brownian Motion and Its Applications In The Stock Market. USA: Illinois Institute of Technology.

Gillespie, D. T.-U.-2. (1996). Exact numerical simulation of the Ornstein-Uhlenback process and its integral. physical riview E54, no.2: 2084-2091.

Hull, J. C. (2002). Fundamentals of Futures and Options Markets. New Jersey: Pearson Prentice Hall.

Rubinstein, R. Y., \& Kroese, D. P. (2008). Simulation an the Monte Carlo Method. New Jersey: John Wiley \& Sons.

Siahaan, H. (2008). Seluk Beluk Perdagangan Instrumen Derivatif. Jakarta: Kompas Gramedia.

Smith, W. (2010). On the Simulation and Estimation of the Mean-Reverting OrnsteinUhlenbeck Process.

Tandelilin, E. 2. (2011). Analisis Investasi dan Manajemen Portofolio. yogyakarta: BPFE. 